\title{
AN EXPRESSION OF CULTURAL CHANGE: INVISIBLE CONVERTS TO PROTESTANTISM AMONG HIGHLAND GUATEMALA MAYAS
}

\author{
Liliana R. Goldin and Brent Metz \\ State University of New York, Albany
}

The process of religious conversions to Protestantism is widespread and rapid in the underdeveloped world, and the numbers in Latin America are especially significant (Stoll 1990). It affects urban and rural peoples of varied cultural and ecological backgrounds. Of ten, major economic changes are either attributed or related to the signif icant ideological shift associated with religious conversion. The nature of the changes taking place as individuals or families convert is complex. In Latin America, and particularly in Guatemala, people may convert for reasons as varied as the popularity of a Protestant political leader (president Rios Mont), an earthquake, and the ongoing violence (Annis 1987). Nash (1960) found alcoholism to be one of the major reasons for conversions, and refers to Protestantism as the Alcoholics Anonymous of Maya Indians. Economic (Redfield 1962; Wasserstrom 1976; Brintnall 1979), political (Falla 1980), and social reasons (Reina and Schwartz 1974) have been cited as the basis for conversion to Protestantism in the area.

Some scholars have pointed to the tendency of studies to provide limited attention to experience, discourse analysis, and other processes of identity change within which conversion may be understood (Heirich 1977; Snow and Machalek 1984; Taylor 1976). Historical accounts of Protestantism's introduction to Latin American countries (i.e., Garrard Burnett 1990; Stoll 1990; Rose and Brower 1990) elaborate on the type of discourse that different denominations use in their missionary enterprises, of ten through development or education projects. The association of economic development through progress and modernization with Protestantism has been explicit in the teachings of Protestant missionaries and writers (Dennis 1906) and the social and economic benefits of associating with Protestants is emphasized by numerous recent studies (e.g., Tapp 1989; Manning 1980; Green 1978).

In the case of western Guatemala discussed below, the connections of trade, capitalization, and conversion are apparent. As suggested, the reasons for conversion are complex, and while their identification is important, so are the implications of the rapid change and the way in which it is taking place (Scotchmer 1986). The rate of religious change highlights the deeper changes that are taking place at all levels of society and may indirectly affect further changes. The impressive showing of Protestant candidates in the national elections of 1990 is significant, as it reflects the continuation of conservative trends within a framework of North American, free market, and modernization discourse in the midst of repression. The new political alliances of ten overlap with religious and economic interests that presently serve the interests of relatively few Mayan 
Indians. However, conversions and the seemingly corresponding conservative ideology arise from all sectors of the same population. Mayas that were long repressed call now for "order" with the infamous implications that this may have in Guatemala. People who are changing occupations, are experiencing a redefinition of values and priorities (Goldin, in press). Ethnic identities and new class formations are forcing people to question themselves and their neighbors. The study of conversion seems to be one way of elucidating profound social and economic transformations. ${ }^{1}$

Here we consider religious change as one variable in a gamut of related cultural changes. By analyzing the value statements of both Catholics and Protestants, we are able to identify a substantial group of Mayas that have experienced important ideological/cultural changes of ten associated with Protestantism and the Protestant Ethic. This is further revealed in the analysis of people's discussions of their decisions to convert or to remain Catholic as they assessed their own lives. We explore the possibility that many nonconverts who hold positive views of Protestants have "accepted" (in the language of Protestants) the new moral code, and have reshaped their world views to coincide with those of Protestants. However, these individuals have not formally converted, as this would imply a public commitment to a lifestyle with which it is difficult to comply. In this sense, declared religious affiliation may mean little when examining the relation between social practice and world view. These perceptions are a commentary on the process of social and cultural change, reflecting concurrent processes of accommodation and friction.

Issues of religious change in the community or personal conversion arose in the context of eliciting life histories. It is in this framework that people chose to talk about change, economic improvement, the favorable position of the town with respect to others in the region, and the changes the town has undergone in the last 50 years. Religious change summarizes for many the overall rationalization of a broader, more profound cultural change which people are in the process of experiencing.

\section{RESEARCH SETTING AND METHODOLOGY}

The data for this study were collected between 1988 and the summer of 1990 in Almolonga, Guatemala, where Goldin began research in 1980. Based on categories extracted from qualitative fieldwork, a questionnaire was administered to a random sample of 10 per cent of the population in 1988. The survey covered economic and ideological issues to provide a general framework for the analysis of sociocultural and economic change. Questions addressing people's views of their own religion and ethnicity and those of others were included. Catholic and Protestant local interviewers were employed to conduct the survey in the native language (Quiche). Goldin conducted more intensive interviews with a subset of heads of households previously identified in the survey. The families represented households that, while having comparable economic backgrounds in their grandparents' generation, were economically differentiated in 1990. All life histories collected in the summer of 1990 addressed religion in the context of discussing people's lifestyles, major life changes, or the problems they had or continue to have at the time of our research. The collection of life histories was not intended to influence informants' answers to specific questions about religion or religious change, but to allow them 
to place each significant life event in the context they felt most comfortable. The context in which discussions about religion arose provided clues for the understanding of people's perceptions, the process of religious change, and the implications for cultural change. Most respondents who had experienced what they considered beneficial economic changes in their lives, had also converted to Protestantism.

With a population of approximately 12,000 people, of whom 99 per cent are Quiche Maya dedicated to horticulture and trade, Almolonga is conveniently located about five kilometers south of Quetzaltenango, the second largest city in Guatemala (approximate population 100,000). The road between Almolonga and Quetzaltenango was paved in 1983, making communication with the rest of the region easier and more frequent. Almolonga holds its weekly market on Saturdays when large wholesale of vegetables takes place just outside the local market. The people of Almolonga had been known to trade and produce some vegetables throughout the colonial years. However, at the beginning of this century they were dedicated to the growing of alfalfa as fodder and to the provision of grazing fields for animals taken from the north to the south coast. Their vegetable production today, one of the largest in the country (Goldin 1989), is totally oriented towards sale in the markets. Several professional traders have little land but have been able to accumulate considerable capital from their commercial enterprises. As a whole, Almolongueños are considered to be quite progressive and better off than other people in the region.

The results of our survey suggest that approximately 52 per cent of the population of Almolonga is Catholic and 48 per cent Protestant. ${ }^{2}$ This contrasts with the finding that during the generation of the parents of the present heads of household, only approximately 13 per cent of the population was Protestant, and the remaining 87 per cent Catholic. Of the present generation's grandparents, only about 3 per cent were Protestant. This recent and rapid rate of conversion is associated with a decrease in Cofradia participation (civic and religious hierarchy) from approximately 42 per cent during the sample's parents' generation to approximately 26 per cent during the present generation, and a major decrease in the practice of traditional costumbre (rituals associated with the earth and other Maya deities), from approximately 82 per cent during their parents' generation to approximately 42 per cent for the current generation. The decrease of Catholics (both traditional and orthodox) is coupled with the loss of a permanent resident priest in the community. Since 1988, a priest has shared his obligations in Almolonga with two other townships.

The context in which religion appears in people's discourse is suggestive. There are slight differences between men and women but almost without exception, male heads of household talk about religion in the context of their youth and how their parents were very poor, had little or no land, and also drank too much. Of ten the informant himself would refer to his own drinking but proudly emphasize his life change as he converted to Protestantism. 


\section{RELIGIOUS CHANGE IN PEOPLE'S DISCOURSE}

\section{Alcohol Consumption}

Nash (1960) has suggested that many Indians convert to Protestantism as a means of dealing with alcoholism, and indeed the theme of drinking problems was raised in numerous accounts. Sometimes the problem concerned the drinking behavior of the individual and other times it focused on the drinking of family members. In one case, an informant said that his father drank too much, and the informant went to the church looking for relief. Women's accounts of religious conversion of ten appear in the context of discussing their husband's, father's, or brother's drinking. The fact that within the Evangelic church men do not drink was particularly attractive to women subject to abuse from their male relatives when they are drunk. This important incentive prompts many women to try to convince their spouse or other relative to convert while the women and their children have already begun to attend the new church (Bossen 1984:24-6).

For both women and men, it was not drinking per se that initially was objectionable, but rather the suffering that drinking directly brought to the household through its impact on family relations and family economics. However, with the formal adoption of a Protestant moral code that prohibits drinking and links sobriety to God and religion, the act of drinking itself has became a vice to be avoided:

My mother had died, I was alone with my father and he drank a lot and we suffered a lot...my father drank, my father-in-law, and we also drank, and nobody told us anything, my mother-in- law also drank... I stopped drinking eight years ago and then six years ago I changed religions. I changed religions because I suffered a lot, I had nothing. I realized that I could not get out of the situation I was in. Then maybe God touched me. Before, I did not have this house the way it is now [it was smaller]. I tell my children they have to work hard, not to go towards the vice, that I would be dead if I hadn't stopped drinking....Because I accepted the word of God, God gave me a miracle so that my things (cuentas) would work out.

In this account, the informant stopped drinking two years before formally becoming a Protestant. Yet, he claims his life did not change significantly until after he formally converted. He clearly labels drinking as a problem source. However, it was not until he formally embraced the Protestant belief system that God rewarded him by changing his life.

The view that religious conversion merely is a means of coping and obtaining support for drinking problems fails to capture many of the dynamics underlying drinking-conversion dynamics. Alcoholism can have an adverse economic and social impact on the family unit and lead individuals to seek new sources of help, however, Protestantism links sobriety to a broader religious code, thereby promoting more fundamental cultural changes. Acceptance of sobriety in this context fosters acceptance of other aspects of the belief system and vice versa. The importance of these broader links is underscored by the following account:

[things that I used to do]

like drinking, having fun, according to the tradition, but I had problems with that, with alcohol. Then I said "enough!" Because I read the Bible and there is a God, and He is powerful and can make one change. There are groups like Alcoholics Anonymous that can help us, but I think it has to come from someone superior. And since I accepted the new religion I felt a life change. 


\section{Economic Considerations}

Poverty and poor economic conditions were other factors mentioned in accounts of religious conversion. However, as with alcoholism, the underlying mechanisms are more complex than the behavioral translation of a desire for economic improvement. With the growing scarcity of land in the region (Goldin 1989), many Almolongueños were forced to seek alternative means of support relative to traditional milpa production. The result was an increased emphasis on trade, diversification, and participation in the broader market system. The need for constant dedication to this work was in conflict with the maintenance of traditional ritual cycles. Traditional Catholicism was associated with cofradia activities, patron saint celebrations, and other festivities that served as significant symbolic spaces in the agricultural cycle. The traditional life had room for these times of joy and celebration, even when alcohol consumption extended the period beyond the time of the Fiesta itself. The new occupation, professional trade, was guided by a different set of temporal and spatial assumptions (Goldin 1987, 1989). In this framework converts see traditional activities as "interruptions" of productive time, a "waste of time." They are proud to emphasize that they do not take much time to rest, Saturdays and Sundays, and use the time of the patron saint celebration to go on business trips:

I don't miss the fiestas because for example last year the patron saint day I left for my trip to Peten, to work. I was only interested in God and the things that most help me in my life.

The "miracle" that God gave people so that they could improve economically was the enforcement of a code of behavior already considered appropriate, but contradictory to the traditional lifestyle. This code was not necessarily new; it was gradually acquired through significant occupational changes brought about by the scarcity of land (Goldin, in press). However, the broader Protestant belief system served to validate the behavioral code and link it to a higher moral system.

Many of the informants discuss the importance of good and bad investments. For example, some state that the "big changes" in Almolonga are due, in part, to the fact that those who do not drink can now invest their money better:

Things changed in Almolonga because there is much trade. Because of the religion, people stopped drinking and now they only think of work and business. Before, many people had vices and many had to sell their land for that reason, but now they are taking good care of it.

\section{Another informant states:}

You invest money in beneficial things...one does not waste money to have fun in places that are not good [healthy], then one can see economic progress... I think that the basis of development is the change in religion... because $I$ have seen and felt that you earn it and invest it in good things to improve the home, the education of the family, and all that... When one does not have that principle one always thinks in having fiestas, and you know that the fiestas are lost investments... what Catholics earn they invest wrongly.

A good investment in this view is one associated with material gains. Profit is the measure of success. A bad investment (food and liquor in a traditional fiesta) is one that may generate social, political, and other rewards, but not economic ones. These definitions represent a significant cultural shift from earlier views of 
fiestas and the cofradias. People insist that you do not become Protestant to become rich, but that as you convert you start investing your money better and then you improve your economic situation. Investing well also implies multiple investments and diversification. Again, these notions depart from milpa agriculture and traditional lifestyles ${ }^{3}$ and emphasize the need for alternative means of subsistence.

\section{Commitment}

An interesting concept that arose frequently in people's accounts was that of commitment. Converting or remaining Catholic is, in the words of the informants, a commitment to comply with a larger set of moral standards; a public statement. Specifically, conversion means a commitment to sobriety, to honesty, to monogamy, and to refrain from traditional celebrations. Many of the informants proudly emphasize commitment. At the same time, there were some who, even though they converted, expressed nervousness about the nature of the commitment:

We have to set an example, a different attitude. We have to be positive. Of course there is a risk that I might not fulfill everything I said I would when converting. I have to be good, but one is human and can make mistakes, but we try not to follow the old traditions. It is a commitment with God.

The act of making a public commitment through conversion increases pressure on new converts to obey the new moral code. Just as important, this commitment enhances the adoption of the broader Protestant belief system. Studies have shown that the act of public commitment is sufficient to bring about fundamental changes in individuals' beliefs so as to make those beliefs consistent with the commitment (e.g., Cialdini 1985). Such a process may be operative here.

\section{Solidarity and Support}

Another motivation of ten discussed when reflecting on conversion is the need for community solidarity to help and support other people in the town, and the lack of it. Many individuals who converted indicated that they were not interested in participating in cofradias or other traditional communal activities. Where could people get help, advice, and guidance when having problems? The Protestant church meets these needs with its frequent weekly meetings in which the minister addresses people's lives and problems in his sermons. Members of the church become "brothers" and "sisters," terms of address that reinforce closeness and trust. The Church becomes a large extended family, leveling all members, including Ladinos, to fairly egalitarian terms.

I felt a need to live together (convivir) with the people of my town, because when I was Catholic it was as if I was more isolated from society; because I saw Christians to be more united, to work together. In case of problems, there were all the people.

Solidarity is also an important theme of Catholicism in Almolonga. However, the different strategies used to promote solidarity in the respective religions are striking. Traditional Catholics tend to rely more on social activities and fiestas whereas Protestants emphasize the promotion of unity by working on common goals and problems. 


\section{Empathy and Relevance}

The themes of relevance and understanding were also raised. Not only is it important to people that the minister advises them on general life matters, it is important that the ministers are local people who speak the same language, Quiche, and share the same cultural framework. The minister is not an outsider, as the Catholic priest of ten is, but someone from the town. He knows the people, their "suffering and the backwardness resulting from constant cofradia participation," and deeply understands his congregations' interpretations of his sermons and Bible readings. Unlike the outsider, he is said to have the profound power of translation in its larger, more holistic sense.

Ministers try to relate Protestant doctrine with people's everyday experiences, and cite examples to which most people can relate when explaining the Bible. They talk about family feuds over land, environmental problems, poverty and limited resources, and do so in informal and simple terms. The Catholic church, someone said, "did not provide us with teachings. [The teachings] contribute to a good life, a life with guidance and orientation." Another informant states:

The minister, besides religion, he gives you advice on how to improve your socioeconomic situation. Such as: "avoid fiestas, dress better, invest money, buy a car, enjoy development..." Because it would be useless to obtain money if one will continue living like before, you have to get a modern lifestyle.

\section{Specific and General Codes of Life}

Many of our informants discussed the importance of having specific behavioral codes for knowing how to act that are grounded in a more general moral code for life and salvation. For example, the "new" moral code discusses the love and respect for one's spouse and family (as does the old), but it is the strict behavioral regulations which, especially from the perspective offered by women, imply an improvement in their own lives. Studies report the positive effects that conversion seems to have on women, either by allowing them access to literacy (Sered 1990), compensating for loss of prestige, as with Navajo women (Blanchard 1975), providing advice, and, as in our case, by restricting alcohol consumption and polygyny in Guatemala (Bossen 1984). The apparent freedom of Catholics "to do whatever one wants" of ten translates into freedom to drink, to womanize, to misbehave, according to Protestants. In other words, this freedom is perceived as leading to excess.

Religious change is regarded as an "improvement" of the person and the group and an acceptance of a new, broad moral code. The change is major and facilitated by "God's help." Salvation itself constitutes an ultimate statement, the proof of total achievement. Salvation of the soul corresponds to salvation in daily life. In fact, discussions of religion primarily appear in the context of change and progress in life rather than spiritual, cosmological, or theological concerns:

The truth is that since I accepted the Gospel I felt a change in my life. I felt more responsible, more dedicated to my work, my home. I stopped all traditions and fiestas because most of what you see there is liquor. 


\section{MUTUAL PERCEPTIONS}

With the rapid increase in religious conversions and the fundamental shift in culture and ideology occurring concomitantly, we expected polarization between existing religious groups within Almolonga. As Catholics have seen their numbers diminish and others adopt a lifestyle that is at odds with tradition, we expected a growing hostility and negative view towards Protestants. Similarly, as Protestants leave behind their past identities and associate with a new lifestyle, people who retain their old ways would be viewed with some disdain. Our analysis of life histories and our recent survey suggest, however, that this is not the case.

Our questionnaire asked people ( 180 heads of households) to comment about and describe both Protestants and Catholics, among other groups of people. The questions were open-ended so that people were free to choose the style and categories of answers. Interviewers were both Protestant and Catholic. We expected the religion of the interviewer would bias people's responses but our results revealed that answers did not differ appreciably as a function of the religious affiliation of the interviewer. This was probably due to the fact that the questions were asked in the context of a broader set of questions about the individual's current life and that of his family as a whole. The kinds of categories supplied by respondents in their characterizations of Catholics include "go to mass, like fiestas, get drunk, believe in idols, are kind and good, practice costumbre, have not changed, have vices, are backward, have no fear of God, are careless, believe in several Gods, are changing, and like to attend processions." The major categories used to describe Protestants included "they like to go to service, are kind and good, are affectionate, have changed their lives, are different, do not like fiestas, have no vices, set good examples, are true Christians, have fear of God, do not drink, and have the truth."

There were several noteworthy trends in these data. First, as we expected, Protestants were somewhat critical of Catholics. In addition to simple descriptors such as "goes to mass" and "likes fiestas," Protestant characterizations of Catholics tended more frequently to emphasize concepts such as "having vices, getting drunk, believing in idols, and not having a fear of God." By the same token, Protestants were generally self-praiseworthy, mentioning few, negative attributes for the group. In addition to statements about "goes to service" and "doesn't like fiestas," Protestants tended to characterize themselves as being kind and good, setting good examples, respecting god, and representing change and progress.

Surprisingly, Catholics were also generally praiseworthy of Protestants. In addition to the general statements such as "goes to service" and "doesn't like fiestas," Catholics also tended to describe Protestants as kind, good, and setting good examples. In fact, the only clearly negative attribute mentioned by a few Catholics was that Protestants speak negatively of Catholics. Catholics tended to describe themselves as "going to mass" and "liking fiestas." However, nearly one out of five Catholics were critical of other Catholics' vices and beliefs in idols.

The results suggest that Protestants are generally well viewed by Catholics, even by Catholics who are relatively traditional (i.e., who practice costumbre and participate in the cofradia). In addition, there are some self-identified Catholics who are critical of Catholics as a whole, whereas this is a relatively rare occurrence for Protestants. The negative views Protestants hold of Catholics probably represent disillusionment with the traditional religion and an incompatibility of the 
religion with emerging lifestyles resulting from other fundamental changes in the township (e.g., land loss). Similarly, as Protestants identify with a new group and experience renewed levels of empathy, solidarity, support, and guidance, their conceptions of Protestants will be generally positive. Of greater interest is the somewhat negative characterizations of Catholics by Catholics. One source of such characterizations may be formal divisions among Catholics themselves, such as members of Catholic Action. However, our life histories suggest another mechanism, namely that a significant proportion of self-identified Catholics have essentially converted to Protestantism, if not formally then ideologically. This conversion is internal and personal; the acceptance of a new belief system. Some Catholics are critical of their own behaviors and traditional practices, but may not be ready to make a formal commitment to the new religion. If they formally converted, they would have to be held accountable by others, both Catholic and Protestants, for their actions. Conversion itself is less a spiritual than a public announcement of a new lifestyle. If this interpretation is correct, these invisible converts would reflect in their views those positive attributes they themselves are trying to emulate.

Several of the people we talked to in our collection of life histories seem to fit into this group. They identify themselves as Catholic who changed much of their lifestyle, are becoming economically successful through the practice of trade and diversification of both crops and activities, and claim to go to Church only "when they have the time." They stopped drinking years ago because they realized it was hurting them and say they would rather not convert to Protestantism because they had "made a commitment to God," or that "this is not a toy, we'd better leave it the way it is." A recent convert says: "I just changed religions, but I wasn't one hundred per cent Catholic. I only went to church for fiestas..."

Many of the recent converts, and probably many future converts, are people who feel isolated. As the communal system is disintegrating, the participation in the cofradias is diminishing, the Catholic church is losing power, and the number of priests is low. ${ }^{4}$ While the Catholic church thought that by conducting mass in Spanish it was getting closer to their people, Mayas view Spanish as the language of power and domination. The message of the Catholic church is said to be foreign and obscure. People are turning to Protestantism, in part, to replace some of their lost sources of solidarity, for support, and as a tool to enhance their self-esteem. In fact, "building up of self-esteem" is of ten found in the Protestant discourse.

In sum, the positive perceptions that many Catholics have of Protestants result from the fact that they probably have already undergone some change in their own general attitudes about life; i.e., good citizenship, obligations towards family and community, and overall morality. The number of invisible converts is probably substantial. It is evident, however, that public affiliation with a religious group, particularly Catholics, does not necessarily correspond to one's deeper, internal self-identification. Those Catholics, not formally converted, may be functional converts in as much as their models of reality have changed.

\section{THE PROCESS OF CULTURAL CHANGE}

The fundamental cultural changes that are rapidly occurring in Almolonga are fostered by many of the mechanisms discussed above in the context of religious change: new leadership by responsive and empathic ministers who speak the 
language of the people; specific guidance as to proper behavior as well as more general moral guidance; the promotion of solidarity and togetherness by the formation of clearly identifiable networks (e.g., addressing each other as "brother" and "sister") and working towards common (newly established) goals; the linking of everyday behavior to broader religious salvation (and achievement of earthly success); public commitment as a means of inducing behavioral conformity and belief consistency; a responsiveness to the changing needs of the community as a result of land loss and occupational changes; and a responsiveness to the problems of both men and women in the context of the family unit.

There are several cultural changes associated with the new ethic, shared by most converts and many nonconverts alike. First, there is a greater emphasis on competition. Numerous informants' accounts stressed the importance of bettering oneself and using other individuals as a standard for comparison. For example, in the context of material change, people are told that they should dress better and have a better house. Competition with your neighbor is now viewed as a positive trait, reflecting a desire to prosper in life:

If my neighbor is dressing better, if my neighbors live better, then I tend to do the same thing, that [strategy] was for me very beneficial.

Second, there is the stress on individualism and the bettering of oneself by relying on one's own efforts and hard work. This theme has been noted by other researchers and is apparent in this study. However, we also found that such individualism is fostered by an appeal to community support and solidarity. Thus, shared community ideals, in the past fulfilled through cofradia activities, are now being fulfilled through the participation in the new community of "brothers and sisters" who work towards the common goal of self-betterment. It is paradoxical that while the new ideology emphasizes individualism, competition, personal improvement, and social and economic progress, among other values, it does so by appealing to fundamental Maya values associated with community solidarity, support, and guidance.

A third important change is the shifting criteria that people use to define success in life. The individual's world is increasingly viewed in terms of good and bad investments, where material gain and personal wealth become a measure by which individuals determine their personal and communal progress.

A fourth set of cultural changes focuses on shifts in social activities. New occupational trends (professional trade) are in harmony with the new religion (cf. Paul 1987). There is no time for celebrations that last several days and interrupt the commercial calendar. The agricultural calendar had time and space for ritual and social drinking, and prolonged, intense fiestas. The pace of the merchant is the pace of the new market society that has led more and more individuals away from the cultural heritage of the celebrations and fiestas.

Related changes concern leisure activities and the cultural traditions that are communicated in the context of leisure. With the elimination of fiestas and other ritual celebrations, and with the absence of alcohol, a whole new type of activities associated with relaxation and "healthier" recreation has been created. This has increased the practice of sports, games, travel to visit nearby sights, or time spent with the family.

Discussions of religious conversion in the literature address the issue of determining whether changes are behavioral or ideological (Blanchard 1975:46); 
i.e., whether they are based on conviction or belief rather than in action (Kammerer 1990:288). The case of Almolonga suggests that conversion, and overall ideological change, has to do with what Cuchiari's (1988:418) analysis of pentecostalism in Sicily described as a "transformation directed toward more integrative systems of meaning, personal autonomy and moral responsibility." This transformation, as suggested by Jules-Rosette $(1976: 132,164)$ is constantly relived and ratified, and activates an inner struggle between competing representations of the world. The ideological transformations may reflect less on cosmological and spiritual domains than on political spheres of power and control; e.g., new commercial elites ally with conservative factions, as is the case in Brazil (Hoffnagel 1980:118), Belize (Birdwell-Pheasant 1980), Ethiopia (Hammer 1985), and currently in Guatemala. In fact, conversions in Guatemala are closely related to ideology introduced by North American missionaries after the reforms of Justo Rufino Barrios in 1870. These were accompanied by the introduction of the American model of life promoted by The Central American Mission since 1896 (Garrard Burnett 1990). The encouragement to develop commerce, to become wealthy or wealthier than others as a reward from God rather than a cause for supernatural and social punishment (envy, disease), and to improve the standard of life, are all principles that underlie the change.

\section{CONCLUSIONS}

Protestantism offers individuals a set of specific codes about proper behavior that directly address situations that have led to economic and familial stress (e.g., drinking, polygyny). These codes are linked to a broader belief system rooted in God's word. Formal adoption of the codes fosters acceptance of the broader belief system and reassures individuals with the promise of religious salvation. The codes have favorable implications for all members of the family, thereby engendering family support. Adoption of the belief systems and codes of conduct require a public commitment on the part of the convert. Although this commitment is viewed with trepidation by some, once made, it opens the door to a strong source of solidarity and support. Solidarity is developed not so much through social mechanisms (as is traditionally the case) but rather from working towards the common goals of economic, social, and familial betterment through individual betterment. Public commitment not only serves to engender support, but further fosters the entrenchment of the belief system within the individual.

The codes and belief systems also are influenced by other major forces affecting the community. Recent land loss coupled with the need to explore alternative occupations have forced new lifestyles on many individuals. The belief systems advocated by Protestants are ones that help validate these lifestyles and give them a moral context. In addition, there is a strong practical focus of the new religion. Ministers speak the language of the Maya and are a source of advice and authority on everyday problems that must be confronted.

A new ideology is being assumed through practice and thought by a large sector of the population of Almolonga. This set of beliefs corresponds with those espoused by Protestantism, but it goes beyond Protestants and represents approximately 60 per cent of the population of the town. Historical and socioeconomic information suggests that the new religion is indirectly tied to ongoing cultural change. More encompassing social and economic changes which 
relate to incorporation in the capitalist system through new activities and degrees of involvement in the market have paved the way for the acceptance of the religion and of the values consistent with it. The fact that converts share the ideology of the new religion with many nonconverts suggests that Protestantism is only partially responsible for general cultural changes. People may choose to discuss change in the context of religion because it is framed in a system of norms and ideas that provides justification and rationality for the more apparent changes the township is experiencing. As always, religion is a source of explanation and argument, but the values it represents exceed the religious realm.

Our study identified several cultural changes that reflect economic and religious transformations. A growing number of individuals are using competition as a means of judging their position in life. Competition is viewed as a healthy process. An increased emphasis on individualism and the bettering of oneself as a means for bettering the community is also evident. Interestingly, this is fostered in the context of a system of support and solidarity that appeals to traditional Mayan values. Success in life is increasingly defined in economic terms and in judgments of good and bad investments interpreted broadly. Social and leisure activities also are being affected. With less emphasis on fiestas and traditional celebrations, new forms of leisure activity are developing that are congruent with the broader belief system.

These values and ideals extend beyond formal converts to Protestantism, but also directly affect Catholics who retain traditional affiliations. Thus; there are "hidden converts" who have adopted many aspects of the Protestant philosophy but who choose not to publicly commit to membership in the Protestant community. This suggestion has important implications for researchers who study the relationship between stated religious affiliation and various political and economic phenomena. The presence of hidden converts may obscure the relationship between conversion variables and other variables when conversion is defined strictly in terms of selfstated affiliation. Indeed, in a previous analysis of the relationship between religion and economic beliefs in Almolonga (Goldin, in press), we observed few significant ideological differences as a function of Catholic versus Protestant affiliation. Part of the reason underlying this was that a significant number of Catholics (about 20 per cent) were espousing non-traditional economic beliefs more consistent with a Protestant perspective than a Catholic one.

Just as there are self-identified Catholics who are functionally Protestants, there are also probably some Protestants who retain reluctance about giving up aspects of their previous religious heritage. Our research suggests the importance of distinguishing between public and private religious affiliation and the distinctions between religious belief systems and religious affiliation.

Profound sociocultural change permeates large elements of Maya society. While committed to being "Natural" (Indian) through the expression of pride in their ethnic affiliation, the widespread use of their native language, the wearing of traditional women's clothes, and many other cultural traits, they have changed many other beliefs related to nature, the supernatural, work, accumulation, and other features that used to be identified with Maya traits associated with the ideology of corn production. ${ }^{5}$ This case study provides additional evidence to the complex and intriguing fuzziness of ethnicity as a category of identification. Religious linkages, values, and apparently indelible beliefs may be removed or 
transformed, but the social self continues to re-define itself as an enduring but different entity.

\author{
NOTES
}

1. Some of the specific mechanisms that we identified as potentially relevant to the conversion process and that, in some cases, have only been indirectly discussed in the conversion literature include (1) group solidarity and support, (2) responsive and empathic religious leaders, (3) providing specific behavioral codes and guidance in everyday life, (4) linking everyday behavior to higher moral codes, (5) working towards common goals, (6) the role of public commitment, (7) the strategy of appealing to both men and women in the family unit, and (8) responsiveness to economic, social, and political constraints.

2. Many Protestants seem to have converted from Orthodox Catholicism rather than from Traditional Catholicism, as if the former were a stage towards Protestantism. The distinctions between Orthodox and Traditional Catholicism were elicited through qualitative research. In the formal survey, people identified themselves as either Protestant or Catholic.

3. This does not imply, of course, that this lifestyle did not involve any other activity outside milpa agriculture; peasants often sold the excess of their production at the market and occasionally produced complementary crops, among other activities. It is the emphasis on the diversification of investments and multiple businesses which is here noted.

4. See Sexton (1985) on the disillusionment of people with the Catholic Church.

5. Referred by Annis (1987) as "milpa ideology."

\title{
BIBLIOGRAPHY
}

Annis, S. 1987. God and Production in a Guatemalan Town. Austin.

Birdwell-Pheasant, D. 1980. The Power of Pentecostalism in a Belizean Village. In Perspectives on Pentecostalism: Case Studies from the Caribbean and Latin America. ed. S. Glazier, pp.95109. Lanham, MD.

Blanchard, K. 1975. Changing Sex Roles and Protestantism among the Navajo Women in Ramah. Journal for the Scientific Study of Religion 14:43-50.

Bossen, L. 1984. The Redivision of Labor. Albany.

Brintnall, D. 1979. Revolt against the Dead. The Modernization of a Mayan Community in the Highlands of Guatemala. New York.

Cialdini, R. 1985. Social Influence. New York.

Cuchiari, S. 1988. Adapted from Heaven: Conversion and Culture in Western Sicily. American Ethnologist 15:417-441.

Dennis, J. 1906. Christian Missions and Social Progress: A Sociological Study of Foreign Missions. New York.

Falla, R. 1980. Quiche Rebelde. Guatemala.

Garrard Burnett, V. 1990. Positivismo, Liberalismo e Impulso Misionero: Misiones Protestantes en Guatemala 1880-1920. Mesoamerica 11:13-31.

Goldin, L. 1987. The 'Peace of the Market' in the Midst of Violence: A Symbolic Analysis of Markets and Exchange in the Western highlands of Guatemala. Ethnos 52:368-383.

1989. Comercialización y Cambio en San Pedro Almolonga, Guatemala Occidental. Mayab $5: 45-48$.

n.d. Work and Ideology in the Maya Highlands of Guatemala. Economic Beliefs in the Context of Occupational Change. Economic Development and Cultural Change. (forthcoming)

Green, E. 1978. Winti and Christianity: A Study in Religious Change. Ethnohistory 25:251-276.

Hammer, J. 1985. Practice and Change: An Episode of Structural Disjunction and Conjunction among the Sadama of Ethiopia. Anthropological Quarterly 2:63-73.

Heirich, M. 1977. Change of Heart: A Test of Some Widely Held Theories about Religious Conversion. American Journal of Sociology 83:653-680.

Hoffnagel, J. 1980. Pentecostalism: A Revolutionary or Conservative Movement? Perspectives on Pentecostalism: Case Studies from the Caribbean and Latin America. ed. S. Galzier, pp. 111123. Lanham, MD.

Jules-Rosette, B. 1976. The Conversion Experience: The Apostles of John Maranke. Journal of Religion in Africa 7:132-64.

Kammerer, C. 1990. Customs and Christian Conversion among Akha Highlanders of Burma and Thailand. American Ethnologist 17:277-91. 
Manning, F. 1980. Pentecostalism: Christianity and Reputation. Perspectives on Pentecostalism: Case Studies from the Caribbean and Latin America. ed. S. Glazier, pp. 177-87. Lanham, MD.

Nash, J. 1960. Protestantism in an Indian Village in the Western Highlands of Guatemala. The Social Anthropology of Middle America. ed. C. M. Leslie, Alpha Kappa Deltan:30:49-58.

Paul, B. 1987. Five Years of Religious Change in San Pedro La Laguna. A Mayan Community in Highland Guatemala. Paper presented at American Anthropological Association Meeting, November 18-22.

Redfield, R. 1962. A Village that Chose Progress: Chan Kom Revisited. Chicago.

Reina, R., and N. Schwartz. 1974. The Structural Context of Religious Conversion in Peten, Guatemala: Status, Community, and Multicommunity. American Ethnologist 1:157-191.

Rose, S., and S. Brower. 1990. The Export of Fundamentalist Americanism, Latin American Perspectives 17:42-56.

Scotchmer, D. 1986. Convergence of the Gods: Comparing Traditional Maya and Christian Maya Cosmologies. ed. G. Gossen, Symbol and Meaning Beyond the Closed Community. Essays in Mesoamerican Ideas, pp. 197-226. Albany.

Sered, S. 1990. Women, Religion, and Modernization: Tradition and Transformation among Elderly Jews in Israel. American Anthropologist 92:306-318.

Sexton, J. 1985. Campesino: The Diary of a Guatemalan Indian. Tucson.

Snow, R., and R. Machalek. 1984. The Sociology of Conversion. Annual Review of Sociology 10:167-90.

Stoll, D. 1990. Is Latin America Turning Protestant? The Politics of Evangelical Growth. Berkeley.

Tapp, N. 1989. The Impact of Missionary Christianity upon Marginalized Ethnic Minorities: The Case of the Hmong. Journal of Southeast Asian Studies 20:70-95.

Taylor, B. 1976. Conversion and Cognition: An Area for the Empirical Study in the Microsociology of Religious Knowledge. Social Compass 23:5-22.

Wasserstrom, R. 1976. Revolution in Guatemala: Peasants and Politics Under the Arbenz Government. Comparative Studies of Society and History 18:443-478. 